\title{
THE EFFECTS OF MARKETING MIX STRATEGIES ON BRAND EQUITY: MOBILE PHONE SECTOR
}

\author{
Ebru Tümer KABADAYI \\ İnci AYGÜN \\ Çig̃dem ÇİPLI
}

Gebze Institute of Technology, Turkey

\begin{abstract}
The purpose of this study is to investigate the effects of selected marketing mix strategies on equity of brands performing in mobile phone sector. In this context, perceived price, intensity of distribution, advertising campaigns and sponsorship activities conducted for the brand were proposed to be positively effective on the building brand equity. And perceived intensity of price deals performed for that brand was proposed to be negatively effective on brand. To test the research model, data were gathered through a survey in Kocaeli, Turkey. Regression analysis results supported three out of five hypotheses. Statistically significant and positive influences of price, distribution and sponsorship intensity on brand equity were confirmed but the influences of price deals intensity and advertisement intensity on brand equity were not found significant. The findings also reveal that distribution intensity is relatively most important factor in developing brand equity. The results of this study provide some insights into marketing strategies that are utilized to create brand equity and inform managers about effective marketing mix strategies in mobile phone sector.
\end{abstract}

\section{INTRODUCTION}

In intensively competitive markets, branding is still utilized as strategic marketing tools that provide additional value for company products or services, because brands are accepted as a fundamentally effective factor on consumer behavior. The strength of a brand's effect on consumer behavior is represented by the concept of consumer based brand equity. For that reason brand equity is defined as a valuable source of competitive advantages for companies because it is considered as an antecedent of some beneficial market performance components such as market share, profitability, price premium, extension capability etc.
Consequently, the companies strive to create, maintain and increase brand equity by optimally designed marketing mix strategies. But it is a challenging problem to decide true combination of strategies that will be utilized. This point is also crucial for mobile phone sector because of the intensively dynamic structure of the market with the frequent introduction of new modifier brands that have a short life cycle. In this context, the intention of this study is to the expand current state of research on marketing mix strategies' roles in brand equity management by exploring effect of some selected strategies on brand equity for brands performing in mobile phone sector which is still an emerging market in Turkey. General price and place strategies and three promotion strategies consisting of price deal, advertisement and sponsorship strategies are considered. The study begins with the presentation of literature review about these strategies and development of research propositions. In the following section information is given about the research method and analyses. Study ends with the discussion of the results.

\section{FRAMEWORK AND HYPOTHESIS Brand Equity}

Aaker (1996) defines brand equity as a set of assets and liabilities linked to a brand's name and symbol that adds to or subtracts from the value provided by a product or service to a firm and/or that firm's customers and give information about the five dimensions of the construct containing brand loyalty, perceived quality, brand awareness, brand associations and the other proprietary assets. Consumer based brand equity is also defined by Keller $(1993,2)$ as the differential effect of brand knowledge on consumer response to marketing of the brand. And Kim (1990;66) defines brand equity as the latent capacity of beholder 
by evoking a specific set of thoughts, feelings, sensations and associations and states that brand equity refers brand's potential to continuously and regularly influence the behavior and thus stabilizing the demand for an existing product or expanding their purchase behavior to create demand for new products. As Yoo, Dounthu and Lee $(2000 ; 196)$ quoted brand equity creates value for both the customer and the firm, value for the consumer enhances value for the firm. For that reason brand equity is defined as a valuable source of competitive advantages for companies. In some researches brand equity is investigated as an antecedent of some beneficial market performance components. For example Baldauf, Cravens and Binder $(2003 ; 231)$ found that brand equity was a significant indicator of brand profitability, brand sales volume and consumer perceived value. Consequently, the companies allocate huge budgets to create and manage brand equity. Brand equity is a strategic aspect of marketing management and can be created, maintained and intensified by strengthening one of its dimensions (Ramos and Franco,2005;432). Marketing activities for a brand potentially can create value for the brand by improving ability to recall or recognize the brand and/or by creating, maintaining or changing the favorability, strength, or uniqueness of various types of brand associations (Keller 1993; 14) also increasing perceived quality and brand loyalty.

In complex and dynamic markets, it is really hard to plan and implement the effective combination of marketing strategies through this aim. This study emphasize on relative effects of selected marketing strategies including price, distribution, advertising, sponsorship and price deals on building brand equity based on the consumer perception.

\section{Price}

Price is one of the frequently investigated marketing strategies as related with quality. In consumer perspective, generally a positive relationship between perceived price and quality is expected probably because consumers attribute a reason for a high price such as advanced performance, design, prestige etc. That is, consumers perceive price as a cue to product quality (Wheatley and Chiu, 1977; Yoo, Donthu and Lee, 2000; Agarwal and Teas, 2002). Referring consumers perception about the expensiveness of the brand price perception can be proposed to be effective on brand equity since quality is one of dimensions of the brand equity. Thus

H1: Perceived price positively effects brand equity

\section{Distribution Intensity}

Marketing channels are sets of interdependent organizations involved in the process of making a product or service available for use or consumptions (Kotler, 2003, s.505). Distribution channels are independent structures that supply products and services to the customers when and wherever they want. This situation boosts the perception of quality of the brand and becomes effective in constituting brand equity (Yoo, Donthu and Lee, 2000). The perceived intensity of distribution channels means the number of stores in which the customers encounter the brand is high. The highness of the perceived intensity of distribution channels will be effective in displaying a better brand image thereby constituting brand equity (Shirivasan, Park and Chang, 2005, Yoo, Donthu and Lee, 2000). Concurrently, the customers will be more satisfied since they can encounter the brand in many places. The reason behind this satisfaction is the reduced amount of time and effort to find the product when it is needed. Another aspect is the stores in which the product is displayed are important sources of information that affects the process of brand choice. As a result, distribution intensity affects brand equity positively. Based on this views it can be proposed that:

$\mathrm{H} 2$ : Distribution intensity positively effects brand equity

\section{Advertising}

Perceived intensity of the advertising campaigns refers the consumer's perception about how frequently the brands are advertised and how big campaigns are performed for that brand. Since advertising is recognized as a powerful means of creating strong, favorable, and unique brand associations and eliciting positive judgment and feelings (Keller, 2003; 286) perceived advertising intensity may influence brand equity. The increase of perceived advertising intensity would mean that consumers are more often exposed to advertising messages aiming to create awareness and associations. Some researches provide empirical evidence about the effect of advertising on brand awareness and brand image (Ramos and Franco, 2005; Yoo, Dounthu and Lee, 2000). In literature there are some studies revealing that advertising spending can be perceived as a signal of the product quality that will increase the brand equity. For example Kirmani and Wright (1989), Moorthy and Zhao (2000), Barone, Taylor and Urbany (2005) found that consumers' quality perception were influenced by their perception about spending of advertisements performed for that brand. In the study of Yoo, Dounthu and Lee (2000) it was also proposed and supported that advertising intensity simplify consumer's brand choice because brand would be included in consideration set so would to increase brand loyalty. Explaining the effect of advertising intensity on dimensions of brand equity 
above it can be proposed that:

\section{H3: Advertising intensity positively effects brand equity}

\section{Price Deals}

Price deal is one of the incentive tools of sales promotion campaigns which aim to encourage purchase of a product or service in a short time. Although they are used to attract new customers, reward loyal consumers, increase the repurchase rates of occasional users (Kotler, 2003) in literature it is considered as a risky tool for brand management in the long term. One of the approaches explaining this risk highlights that when consumers are exposed to a promotion they attribute a reason for it (Raghubir and Corfman, 1999; 211) and if the attribution is to the brand price deals can cause a poorer quality perception. So as perceived intensity of the price deals increase consumer should to doubt the quality of the brand. Yoo, Dounthu and Lee, 2000; Ramos and Franco (2005) provide evidence supporting this interpretation. Keller (2002;310) also states some other disadvantages of sales promotion activities addressing the possible decrease of brand loyalty , increase of brand switching, and price sensitivity. The following hypothesis can be formulated based on these points:

H4: Price deal intensity negatively effects brand equity

\section{Sponsorship}

Sponsorship can be defined as provision of assistance either financial or in kind to an activity by a commercial organization for the purpose of achieving commercial objectives (Speed and Thomson, 2000; 226). From the view of consumer relations there are some advantages entering into sponsorship arrangements for firms including, to broaden and deepen their relationship with their target market (Keller, 2002; 315) increasing brand awareness and to establish, strengthen or change brand image (Gwinner and Eaton, 1999; 47).

In this study, the effect of perceived sponsorship intensity on brand equity is studied where the perceived sponsorship intensity refers consumer perceptions about the abundance and importance of the events that the brand supports with sponsorships. Since it is valuable in generating awareness for the brand and corporate images in a general sense (Cornwell, Roy and Steinard, 2001 ; 42) sponsorship intensity may influence the brand equity positively. As perceived intensity of sponsorship increase consumer are likely to be more familiar with the brand. Also because consumer would be more exposed to messages aiming to create associations through the intended image brand image would be effected positively. From a similar point of view with advertising spending, sponsorship intensity may be perceived as an indicator of product quality. Thus: H5 Sponsorship intensity positively effects brand equity Research model drawn on the basis of views above is presented in Figure 1 summarizing hypotheses

Figure 1. Research Model

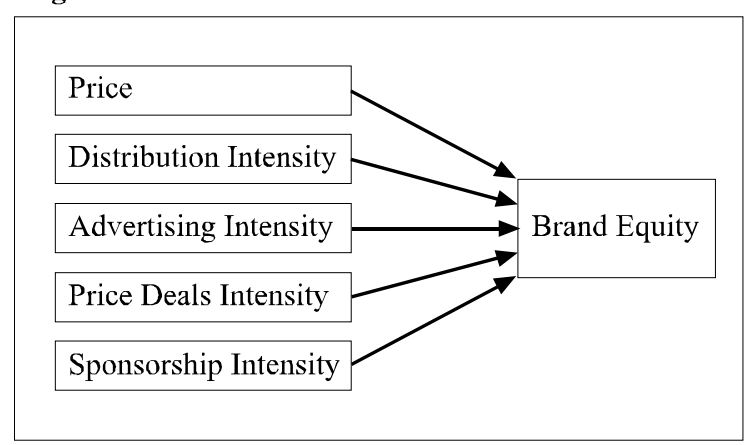

\section{METHODOLOGY Sample}

To test the research model, data were gathered through a survey in Kocaeli, Turkey. Convenience sampling was used to select the sampling frame. A total of 200 questionnaires were hand delivered and 158 completed questionnaires were returned but 11 of them were discarded due to the large amount of missing data. The remaining 147 questionnaires were used in analysis. The characteristics of the sample are presented in Appendix 1.

\section{Measurement}

Brand equity was measured based on an eleven items scale that was adapted from a twelve item scale presented by Bruner, James and Hensel (2001). The scale was a combination of items assessing the dimensions of brand equity including, brand image, price premium, perceived quality, brand loyalty, brand awareness and associations. As they are indicated as valid and reliable scales some constructs of the model including price perception, distribution intensity, advertising intensity and price deals intensity were measured using multi item scales of Yoo, Donthu and Lee (2000) with some manipulations where necessary. Price perception was measured with two items adapted form the original three item scale assessing how expensive consumers perceive the brand is. To measure distribution intensity of the brand, the three item scales were employed to reveal consumers' perception about the number of the stores that are selling that brand. Advertising intensity scale was also adopted from the advertising spending scale of Yoo, Donthu and Lee (2000) that was aiming to asses the consumer's perception about allocated budget for and frequency of the advertisement campaigns performed. Finally price deals intensity measures was adapted from the scale of Yoo, Donthu and Lee (2000) to asses the consumer 
Table 1. Factor Loadings of the Scale Items and Cronbach's Alpha Coefficients

\begin{tabular}{|c|c|c|c|c|c|c|c|}
\hline & $\begin{array}{r}\text { Cronbach } \\
\text { Alpha }\end{array}$ & Component & & & & & \\
\hline & & 1 & 2 & 3 & 4 & 5 & 6 \\
\hline Brand Equity & ,9224 & & & & & & \\
\hline $\begin{array}{l}\text { The image of } \mathrm{X} \text { is different } \\
\text { from other mobile phone brands. }\end{array}$ & & ,646 & & & & & \\
\hline $\begin{array}{l}\text { The image of X Represents } \\
\text { what I would like to be. }\end{array}$ & & ,785 & & & & & \\
\hline $\begin{array}{l}\text { I would rank this brand as my first } \\
\text { choice if I purchase mobile phone. }\end{array}$ & & ,738 & & & & & \\
\hline $\begin{array}{l}\text { I won't mind paying a higher } \\
\text { price for this brand. }\end{array}$ & & ,498 & & & & & \\
\hline $\mathrm{X}$ is most suitable to my needs. & & ,789 & & & & & \\
\hline $\begin{array}{l}X \text { is the most popular } \\
\text { brand in the category. }\end{array}$ & &, 510 & & & & & \\
\hline $\begin{array}{l}\text { When I need to buy mobile phone } \\
\text { I will think of X immediately. }\end{array}$ & & ,670 & & & & & \\
\hline $\begin{array}{l}\text { When asked about mobile phone brands } \\
\mathrm{X} \text { will come to my mind immediately. } \\
\text { Price }\end{array}$ &, 8905 & ,614 & & & & & \\
\hline The price of $X$ is high. & & & & & & &, 874 \\
\hline $\mathrm{X}$ is expensive. & & & & & & & ,858 \\
\hline Advertising Intensity & ,9057 & & & & & & \\
\hline $\mathrm{X}$ is intensively advertised. & & & & ,780 & & & \\
\hline $\begin{array}{l}\text { The ad campaigns for } \mathrm{X} \text { seem very expensive, } \\
\text { compared to campaigns for competing brands. }\end{array}$ & & & &, 811 & & & \\
\hline The ad campaigns for $\mathbf{X}$ are seen frequently. & & & &, 864 & & & \\
\hline Price Deals Intensity &, 8421 & & & & & & \\
\hline Price deals for $\mathrm{X}$ are frequently offered. & & & & & &, 811 & \\
\hline $\begin{array}{l}\text { Too many times price deals } \\
\text { for X are presented. }\end{array}$ & & & & & &, 823 & \\
\hline $\begin{array}{l}\text { Price deals for } X \text { are emphasized } \\
\text { more than seems reasonable. }\end{array}$ & & & & & &, 863 & \\
\hline Sponsorship Intensity &, 8963 & & & & & & \\
\hline $\mathrm{X}$ sponsors many different sports. & & & & & ,803 & & \\
\hline It is very common to see $\mathrm{X}$ sponsoring events. & & & & &, 872 & & \\
\hline I expect $X$ to sponsor major events. & & & & & ,793 & & \\
\hline
\end{tabular}

perception about frequency of price deals conducted for that brand. To measure the sponsorship intensity a three item scale was used that is adapted from sponsorship ubiquity scale presented by Speed and Thomson (2000) assessing the consumer perceptions about the abundance of the events that the brand support with sponsorships.

Respondent were asked to name the brand of the mobile phone that they bought most recently and to indicate their agreement with each item on a 5-point Likert type scale with anchors $1=$ strongly disagree and $5=$ strongly agree, as related with that brand. Respondents also were asked to answer some questions about their demographic characteristics. A self administrated questionnaire was designed and were pretested on a sample of 47 individuals. After the revision of the some items for the clarity the final questionnaire was developed. 


\section{Validity and Reliability of Measure}

In order to evaluate the construct validity the principal components analysis was conducted using varimax rotation. The results in Table 1 show that each scale items were loaded to relevant factors with strong factor loadings addressing the construct validity of the measure. Cronbach's alpha coefficients were evaluated to ensure the reliability of scales. The results presented in Table 1 confirmed the reliability of the scales with alpha coefficients ranging from 0,84 to 0,92 .

\section{Descriptive Statistics and Pearson Correlation Analysis}

The means, standard deviation of the variables and coefficients regarding to Pearson's correlation among these variables are shown in Table II.

Table 2. Mean, Standard Deviations, and Pearson Correlation Coefficients

\begin{tabular}{|c|c|c|c|c|c|c|c|c|}
\hline & Mean & Std. & & & & & & \\
\hline & & Deviation & 1 & 2 & 3 & 4 & 5 & 6 \\
\hline 1. Brand Equity & 3,4888 & 88930 & 1 & & & & & \\
\hline 2. Price & 3,2279 & 1,01737 &, $419^{* * *}$ & 1 & & & & \\
\hline 3. Distribution Intensity & 3,4694 & 1,01041 &, $573 * *$ &, $389^{* *}$ & 1 & & & \\
\hline 4. Advertising Intensity & 3,2925 & 1,02399 &, $433 * *$ &, $330^{* *}$ &, $598 *$ & 1 & & \\
\hline 5. Price Deals Intensity & 2,8175 & 83728 & ,258** &, $212^{* *}$ & $268 * *$ &, $325^{* *}$ & 1 & \\
\hline 6. Sponsorship Intensity & 3,2449 & 87353 &, $440 * *$ &, $253^{* *}$ & $, 4,59 * *$ &, $480^{* *}$ &, $404^{* *}$ & 1 \\
\hline
\end{tabular}

\section{RESULTS}

To test the research model linear multiple regression analysis was performed using SPSS 11,5 with brand equity as the dependent variable and marketing mix strategies as independent variables. Results summarized in Table 3 show that model was significant at $\mathbf{p}<, 001$ and adjusted $\mathrm{R}$ square $=0,387$ meaning that constructs included in the model explained approximately $40 \%$ of the variation in brand equity.

Table 3 also presents the standardized beta coefficients indicating the relative effects of marketing mix strategies on brand equity. These results show support for three of five hypotheses. H1, hypothesis proposing a positive effect of the high price perception about a mobile phone brand should effect the equity of that brand was confirmed with 0,206 beta coefficient at $\mathrm{p}<0,01$. Positive effect of the perceived distribution intensity on brand equity was also significant at $\mathrm{p}<0,01$ and with a strong beta coefficient of 0,375 , supporting the $\mathrm{H} 2$. It is evident from the results that perceived intensity of the advertising campaigns does not have a significant effect on building brand equity so $\mathrm{H} 3$ was rejected.
$\mathrm{H} 4$, hypothesis proposing that price deals intensity should be negatively effective on brand equity, was also rejected. But the consumer perceptions about the abundance of the events that the brand support with sponsorships are found to be positively effective on building brand equity with beta coefficient 0,185 at $\mathrm{p}<0,01$.

Table 3. Regression Analysis Results

\begin{tabular}{|l|r|r|r|}
\hline & $\begin{array}{r}\text { Standardized } \\
\text { Beta Coefficients }\end{array}$ & $\mathrm{t}$ & Sig. \\
\hline (Constant) &, 206 & 3,321 &, 000 \\
\hline Price &, 375 & 4,371 &, 003 \\
\hline Distribution Intensity &, 043 &, 507 &, 306 \\
\hline Advertising Intensity &, 025 &, 342 &, 366 \\
\hline Price Deals Intensity &, 185 & 2,328 &, 010 \\
\hline Sponsorship Intensity &, 408 & & \\
\hline R Square &, 387 & \\
\hline Adjusted R Square & 19,42 &, 000 \\
\hline F & \multicolumn{3}{|l}{} \\
\hline
\end{tabular}

Dependent variable: Brand equity

\section{DISCUSSION}

These studies propose to explore the effects of selected marketing mix strategies on brand equity and results provide some interesting and useful information. Considering the five selected marketing mix strategies together, perceived price was found to be effective on building brand equity. That is, for mobile phone consumers price is a significant indicator of product quality. High price may be perceived as a reflection of advanced technology, design and improved features. Although it was proposed that price deals are negatively effective on the brand equity by harming the image and quality perceptions, we found the price deals have no effect on brand equity. This finding may be still rational since the price deals are not perceived as a promotion activity but a natural outcome of the short life cycle of modifier brands in mobile phone sectors. Sponsorship intensity was found to be effective on building brand equity. This shows the importance of sponsorship activities in creating brand awareness and image in the mobile phone sector. Contrary to some earlier findings advertisements were found to be ineffective in the process of constituting brand equity. The possible reason of this finding is that advertising were considered together with sponsorships. This finding can be interpreted as the overshadowing effect of sponsorship leading the customers to believe that sponsorship is a direct indicator of power, trustworthiness, image of the corporate brand and effective on consumer behavior while advertisement is 
only related to the efforts of promoting the image of product quality for numerous modifier brands. Beside other effective factors, it is seen that the most effective strategy for constituting brand equity is to establish an intensive distribution channel. For instance, in the mobile phone business, dealers transmit information about the rapidly changing models of new phones to the customers; then they become aware of the brands and develop a better perception of about their quality and images.

As for the managerial implications, in order to enhance brand equity (i.e., brand awareness/brand associations, brand loyalty and perceive quality), in rapidly changing industries, we should use effective and intensive distribution channels, promote sponsorship activities; and create effective price strategies. We can conclude that the short product-brand life cycle feature of the mobile phone sector plays an essential role in developing an effective marketing mix strategy for constituting brand equity.

\section{REFERENCES}

Aaker, David A. (1996), Building Strong Brands, Free Press, New York

Agarwal, Sanjeev and R Kenneth (2002), CrossNational Applicability of a Perceived Quality Model, The Journal of Product and Brand Management.11, 4/5, pp. 213-237

Baldauf, Artur; Cravens, Karen S.; Binder, Gudrun (2003) Performance Consequences of Brand Equity Management: Evidence from Organizations in The Value Chain, The Journal of Product and Brand Management, 12, 4/5; pp. 220-234

Barone, Michael J.; Taylor, Valerie A.; Urbany, Joel E. (2005), Advertising Signaling Effects for New Brands: The Moderating Role of Perceived Brand Differences, Journal of Marketing Theory and Practice, 13, 1,pp. 1-13

Bruner II, G. C.; James, K.; Hensel, P. J. (2001). Marketing Scales Handbook: A Compilation of MultiItem Measures. Vol. 3. Chicago: American Marketing Association

Cornwell, T Bettina; Roy, Donald P and Steinard II, Edward A (2001), Exploring Managers' Perceptions of the Impact of Sponsorship on Brand Equity, Journal of Advertising; 30, 2, pp. 41-51

Gwinner, Kevin P and Eaton, John (1999), Building Brand Image through Event Sponsorship: The Role of Image Transfer, Journal of Advertising, 28, 4, pp. 47-57

Keller, Kevin Lane (1993), Conceptualizing, Measuring, and Managing Consumer Based Brand Equity, Journal of Marketing, 57, 1, pp.1-22

Keller, Kevin Lane (2003), Strategic Brand Management. Building, Measuring and Managing Brand Equity, Prentice Hall.

Kim, Peters (1990), A Perspective on Brands, The Journal of Consumer Marketing, 7, 4, pp.63-67)

Kirmani, Amna; Wright, Peter (1989), Money Talks: Perceived Advertising Expense And Expected Product Quality, Journal of Consumer Research, 16, 3, pp. 344-353

Kotler, Philip, (2003) Marketing Management, 
International Edition, Prentice Hall,

Moorthy, Sridhar and Zhao, Hao (2000), Advertising Spending and Perceived Quality, Marketing Letters; 11, 3 pg. 221-233.

Raghubir, Priya and Corfma, Kim (1999) When do Price Promotions Affect Pretrial Brand Evaluation?, Journal of Marketing Research, 36, 2, pp. 211-223

Ramos-Villarejo, Angel F and Sánchez-Franco, Manuel J (2005), The Impact of Marketing Communication and Price Promotion on Brand Equity, Journal of Brand Management; Aug 12, 6; pp. 431444

Speed, Richard and Thompson, Peter (2000), Determinants of Sports Sponsorship Response, Academy of Marketing Science. 28, 2, pp. 226-238

Srinivasan, V; Park, Chan Su and Chang, Dae Ryun (2005), An Approach to the Measurement, Analysis, and Prediction of Brand Equity and Its Sources, Management Science, 51, 9, pp. 1433-1448

Yoo, Boonghee ; Donthu, Naveen and Lee, Sungho (2000), An Examination of Selected Marketing Mix Elements and Brand Equity, Academy of Marketing Science, 28, 2, pp. 195-212

Wheatley, John J. and Chiu, John S. Y. (1977), The Effects Of Price, Store Image, And Product And Respondent Characteristıcs On Perceptıons Of Quality, Journal of Marketing Research, 14, 2, pp. 181 


\section{APPENDIX}

Appendix 1. Sample Characteristics

\begin{tabular}{|l|r|l|r|r|r|}
\hline & Percent & & & & Percent \\
\hline GENDER & & MARITAL STATUS & & MONTHL HOUSEHOLD INCOME & \\
\hline Male & 68,5 & Single & 43,2 & Less than 450 YTL & 3,5 \\
\hline Female & 31,5 & Married & 56,8 & $451-750$ YTL & 7,7 \\
\hline AGE & & EDUCATION & & $751-1500$ YTL & 35,7 \\
\hline From 14 to 44 & 20,1 & Elementary school & & 1501-2000 YTL & 21,0 \\
\hline From 25 to 34 & 38,8 & High school & 8,3 & 2001-3000 YTL & 15,4 \\
\hline From 35 to 44 & 26,8 & University & 40,0 & $3001-5000$ YTL & 13,3 \\
\hline From-45 to 54 & 13,9 & Mater/PhD & 44,8 & 5001-8000 YTL & 3,5 \\
\hline From 55 to 64 & 0,7 & & 6,9 & & \\
\hline
\end{tabular}

